\title{
Potential sources of interference on Abeta immunoassays in biological samples
}

\author{
Hugo Vanderstichele ${ }^{* 1}$, Erik Stoops ${ }^{1}$, Eugeen Vanmechelen ${ }^{1}$ and Andreas Jeromin ${ }^{2}$
}

\begin{abstract}
Therapeutic products that depend on the use of an in vitro diagnostic biomarker test to confirm their effectiveness are increasingly being developed. Use of biomarkers is particularly meaningful in the context of selecting the patient population where the therapeutic treatment is believed to be efficacious (patient enrichment). Currently available'researchuse-only' assays for Alzheimer's disease diagnosis all suffer from non-analyte and analyte-specific interferences. The impact of these interferences on the outcome of the assays is not well understood. The confounding factors are hampering correct value determination in biological samples and are intrinsic to the assay concept, the assay design, the presence in the sample of heterophilic antibodies and autoantibodies, or might be the result of the therapeutic approach. This review focuses on the importance of assay interferences and considers how these might be minimized with the final aim of making the assays more acceptable as in vitro diagnostic biomarker tests for theranostic use.
\end{abstract}

\section{Introduction}

The development of therapeutic compounds that depend on the use of an in vitro diagnostic biomarker test (IVD) to confirm their effectiveness will become more common in the future. Companion diagnostics will ultimately shorten the development time for Alzheimer's disease (AD) therapeutic trials and increase their success rates. When the therapeutic product becomes available, assay information will be used to select (stratification) or exclude (risk assessment) patient populations for a particular clinical study, to optimize dosing regimens, or to identify subjects who will most likely respond to

*Correspondence: hugo.vanderstichele@adxneurosciences.com

'ADxNeurosciences, Technologiepark 4, 9052, Gent, Belgium

Full list of author information is available at the end of the article treatment and will not suffer from side effects (responders, safety). If the outcome of a diagnostic assay determines how a patient will be treated, it is obvious that health care professionals must be able to rely on the quality of the result. Inadequate performance characteristics of an IVD or companion diagnostic biomarker test could expose a patient to preventable treatment risks.

Several research assays for AD biomarkers in cerebrospinal fluid (CSF) evolved over the past decade from proof-of-concept to tools with promising or accepted clinical value. In this disease field, no US Food and Drug Administration-approved assay is available yet on the market, due in part to some drawbacks in their analytical performance characteristics. The US Food and Drug Administration provides more detailed relevant policies for the safety and effectiveness of IVD companion diagnostic devices as used with therapeutics [1].

The AD community has considered for several decades that the $\beta$-amyloid protein $(A \beta)$ might be at the origin of $\mathrm{AD}$, although amyloidopathy is not absolutely specific for $\mathrm{AD}$ [2-4]. A full understanding of its clinical relevance is hampered by (i) the intrinsic nature of $A \beta$, including its aggregation and adsorption properties, (ii) the complexity and heterogeneity of $A \beta$ isoforms, including modifications or different conformational forms, (iii) the presence of confounding factors, (iv) low concentrations of $A \beta$ in biological fluids, (v) high variability in outcomes of each assay between study centers, and (vi) the absence of a reference method or reference materials (relative quantitative assays) $[5,6]$.

\section{Problem statement}

Immunoassays that use antibodies are easy to perform, specific for an epitope or conformation of an analyte, and highly vulnerable towards confounding factors or interferences [5] (in this context, an interference is an effect of a substance present in the sample that alters the correct value of the result). Detailed understanding of the nature, the prevalence, the complexity, the technologyor protocol-dependency, as well as the interactions between different confounding factors is key to define solutions and improve the robustness of the test methods. Cost-efficient and user-friendly integration in the 
product design of assay modifications to reduce interferences, without having an impact on the clinical accuracy, is a major challenge.

Assay interferences are often underestimated, but highly relevant; they have an effect on sample homogeneity and stability, assay precision, or clinical interpretation. Every false result will generate extra cost for the lab and will introduce preventable concerns (through the incorrect message given) for patients, families, and caregivers.

Immunoassays measure the presence (qualitative assay), concentrations (quantitative assay), or changes in concentrations of one or several analytes in a complex mixture of proteins. The affinity of the antibody for the analyte is related to its thermodynamic property (association and dissociation capacity). Antibodies and antigens (or antigen conformations) are in a state of dynamic equilibrium that is concentration dependent. Only a fraction of the total amount of analyte might be detectable by the immunoassays. Notwithstanding the well-known pre-analytical variables [5], the measurement of $A \beta$ by classical immunoassays is complicated by artificial or induced confounding factors, which are illustrated in Figure 1 and discussed here. This review will not focus on antibody-independent techniques, as this could be the subject of future discussions, but discusses in more detail the confounding factors and some possibilities for overcoming them.

\section{Non-analyte-specific interference Confounding factors}

Non-analyte-specific interferences are not necessarily directly linked to one specific analyte, but might be relevant also for other proteins in the sample. Several non-analyte-specific parameters in the product design have a direct effect on the equilibrium constant of the antigen-antibody reaction (for example, temperature, $\mathrm{pH}$, ionic strength), while others have not (for example, antigen and antibody concentration, duration of incubation) [7]. Underdeveloped parameters can explain discrepancies between study results. Problems occur at the level of the assay, the raw materials, or the sample. For example, the $\mathrm{pH}$ of the assay diluent modifies the analytical sensitivity of $A \beta 1-42$ assays [8] and affects the oligomerization state of $A \beta$ [9]. It is well-known that the $\mathrm{pH}$ of CSF increases rapidly after storage at room temperature for a few hours [10], although Bjerke and colleagues [10] did not observe any difference in A $\beta 1-42$ concentration when CSF samples were tested at different pH levels. A $\beta 1-42$ detection in CSF is further influenced by temperature, especially within the AD group [11], affecting its diagnostic use. Non-specific binding can occur also when other components (for example, secondary conjugates, detector mAbs, substrate) directly bind to the solid phase or when aggregated proteins in a $\beta$-pleated sheet conformation bind to each other. The latter was documented for biotinylated mAbs depending on the $\mathrm{pH}$ of the storage buffer [12], an effect that can be prevented by the use of arginine [13].

Each component in the product has to be screened for its influence on the intended use of the assay. If needed, test instructions have to be re-evaluated, even when the product is already available on the market.

\section{Heterophilic antibodies}

Heterophilic antibodies (HAs) are found in a number of healthy and diseased patient samples (5 to 40\%) [14]. These endogenous (mostly polyclonal human) antibodies have a broad spectrum of activity against non-immune immunoglobulins from several species, as well as reactivity towards poorly defined (self) antigens. In contrast, human anti-animal antibodies are directed against well-defined antigens and show high affinity. Their presence can be the consequence of the administration of an exogenous antibody, such as from treatment with therapeutic antibodies. The relevance, occurrence, and importance of HAs as a confounding factor for the measurement of CSF A $\beta$ have yet to be fully described.

HAs have weak affinity and are multispecies specific. The interfering antibodies are of the IgG, IgM or IgA type. Generally, HAs are directed to the Fc part (antiisotypical interference, such as rheumatoid factor), while anti-idiotypical interfering antibodies bind to the highly variable Fab portion of the molecule (an anti-idiotypical antibody is directed towards the antigen-binding site of another antibody; the antigen binding site of this antibody can be similar in structure to the original antigen).

The concentration of HAs is higher in blood samples than in CSF [15]. If plasma samples from the same subject are collected and tested over time, the interference will be visible in each sample from the affected subject, independent of the technology platform. Also, for low abundant proteins such as $\mathrm{A} \beta$ oligomers, positive signals are eliminated (plasma) or reduced (CSF) when assays are repeated in the presence of HA-blocking factors [16]. Small amounts of HAs will immediately affect the quantification of low-abundance proteins, especially when the dilution factor for the sample in the assay is limited, unless HA-reducing buffers were included in the test concept during the development phase of the product.

HAs are not directly visible in single analyte immunoassays. They can be identified by replacement of one antibody (capture mAb, detector mAb) with a nonanalyte-specific antibody [17], using antibodies from another species, by selection of assays from other vendors, or (maybe in part) by the absence of parallelism in serial dilutions of the sample. In the latter case, no 


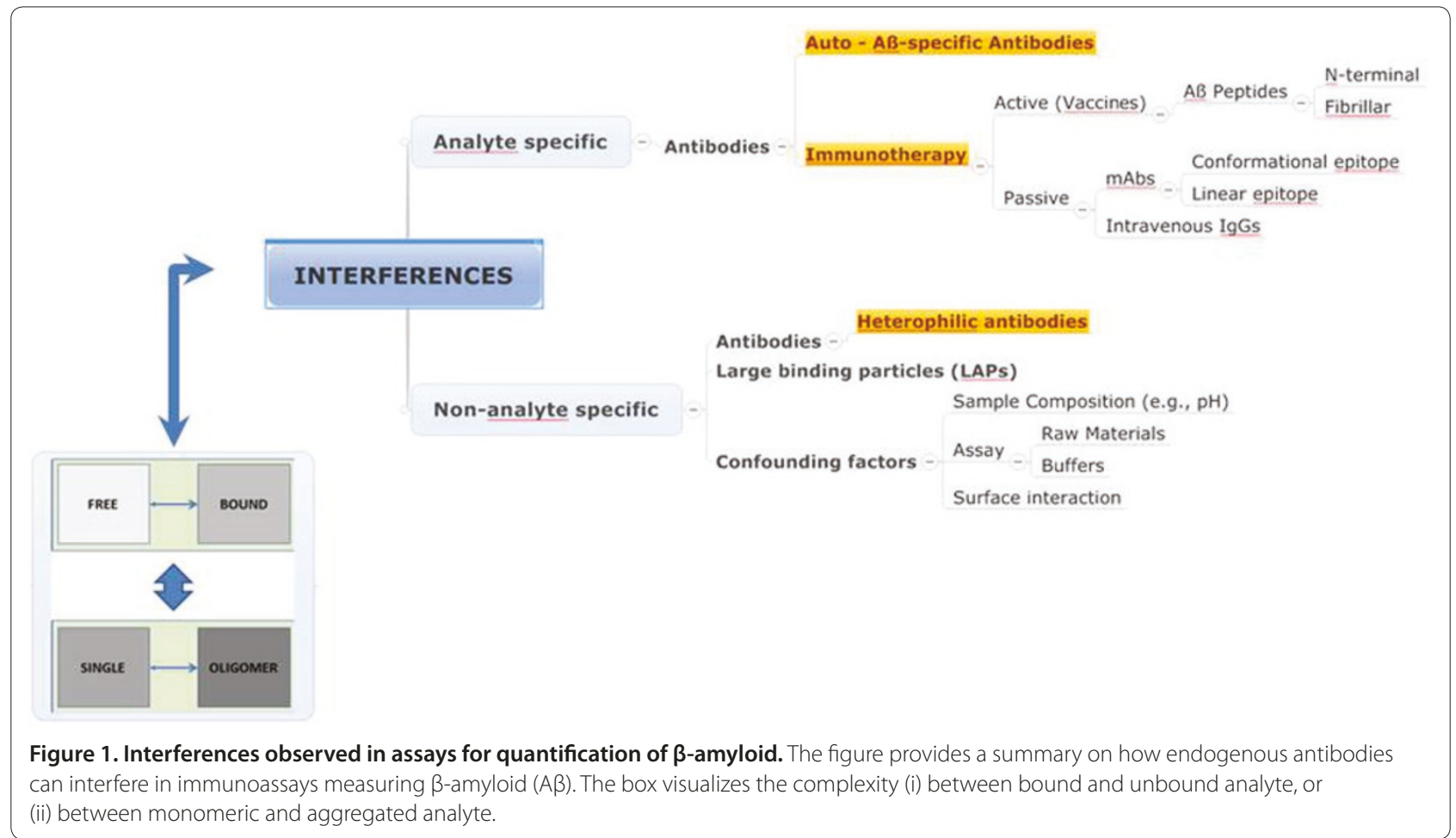

experimental evidence is available to date that HAs are the major confounders.

HA interference can be minimized by assay modifications or sample pre-treatment. At the assay level, interference is minimized by (i) replacement of mAbs by Fab fragments, humanized antibodies, affibodies or aptamers [18], (ii) the use of ready-to-use blocking buffers, detergentia, heterophilic blocking tubes (for example, Scantibodies) or affinity discriminator buffers (for example, LowCross buffer from CANDOR Biosciences, Wangen im Allgäu, Germany), or (iii) the addition of well-controlled non-immune mouse IgG or animal serum (this will not neutralize the anti-idiotypic or anti-anti-idiotypic forms of HAs [19]).

Sample-pretreatment procedures have already been implemented in commercial assays for A $\beta 1-42$. Increased levels of free $A \beta 1-42$ were noted after dilution of EDTAplasma samples in detergent-containing buffer [20] or after dilution of CSF $[10,21,22]$. If compatible with the properties of the analyte, HAs can be removed by heating $[8,10]$, although this is not a customer-friendly approach and might be detrimental to non- $A \beta$ analytes to be analyzed in the sample. Bjerke and colleagues [10] reported a higher increase of CSF A $\beta 1-42$ after heating of $\mathrm{AD}$ samples, resulting in reduced clinical accuracy. Extraction of HAs prior to analysis by depletion of IgG (protein A, protein G) [16], polyethyleneglycol precipitation, or pre-absorption with human gamma globulin-coated beads/Protein L-coated beads [23] has been proposed for other analytes. These extraction procedures will add more cost and workload to the assay used in routine clinical testing labs.

The improvement methods described above might be an excellent approach for one analyte, detrimental to another, and only applicable to one specific sample type. The exact impact of any assay changes on clinical outcome has to be qualified.

\section{Analyte-specific interference $A \beta$ autoantibodies}

Analyte-specific interferences will directly compete with the quantification of $A \beta$ in immunoassays. The prevalence of analyte-specific interferences in modern (blocked) two-site immunoassays is very low $(<0.05 \%)$. The relevance, occurrence, and importance of auto-antibodies as a confounding factor for CSF A $\beta$ measurements are uncertain at present due to a lack of wellcharacterized and validated detection systems and are a subject for future studies.

The clinical relevance of auto-antibodies against $A \beta$ is still unclear, related in part to the urgent need for harmonization of the detection methodologies. The introduction of $A \beta$ immunotherapies will further accelerate the development of harmonized immune biomarkers (Table 1).

Auto-antibodies in AD can influence the IgG-based clearance system for amyloidogenic proteins [24], modulate plaque removal [25], be indicative for dysfunctional 
Table 1. Passive immunotherapy with monoclonal antibodies

\begin{tabular}{|c|c|c|c|c|}
\hline Drug name & Sponsor & Status & $A \beta$ epitope & Reference \\
\hline \multicolumn{5}{|c|}{ Passive immunotherapy with mAbs } \\
\hline Bapineuzumab & $\begin{array}{l}J \& J \\
\text { Elan } \\
\text { Pfizer }\end{array}$ & III & $\begin{array}{l}1-5 \\
\text { Conformational and linear }\end{array}$ & {$[36,37]$} \\
\hline Solanezumab & Lilly & III & $\begin{array}{l}\text { 13-28 } \\
\text { Linear }\end{array}$ & {$[38,39]$} \\
\hline Gantenerumab & Roche & $\|$ & Conformational & {$[40,41]$} \\
\hline Ponezumab & Pfizer & II (stopped) & $\begin{array}{l}33-40 \\
\text { Linear }\end{array}$ & {$[42]$} \\
\hline Crenezumab & Genentech & $\|$ & $\begin{array}{l}1-15 \\
\text { Conformational }\end{array}$ & [43] \\
\hline BAN2401 & Eisai & । & $\begin{array}{l}\text { Amino-terminal } \\
\text { Conformational }\end{array}$ & \\
\hline \multicolumn{5}{|c|}{ Passive immunotherapy with intravenous lgGs } \\
\hline Octagam & Octapharma & $\|$ & & [44] \\
\hline Newgam & Sutter Health & $\|$ & & \\
\hline \multicolumn{5}{|c|}{ Active immunotherapy, vaccines } \\
\hline ACC-001 & $\begin{array}{l}\text { J\& \& } \\
\text { Wyeth }\end{array}$ & $\|$ & $1-7$ & {$[45]$} \\
\hline CAD106 & Novartis & $\|$ & $1-6$ & [46] \\
\hline $\mathrm{ACl}-24$ & AC Immune & $\|$ & $1-15$ & {$[43]$} \\
\hline Affitope AD02 & $\begin{array}{l}\text { GSK } \\
\text { Affiris }\end{array}$ & $\|$ & Mimick of amino terminus & {$[47]$} \\
\hline
\end{tabular}

A $\beta$, $\beta$-amyloid; GSK, GlaxoSmithKline; J \& J, Johnson and Johnson.

immune signaling [26], reflect blood-brain barrier breakdown [27], or reduce neuritic dystrophy and astrogliosis in mouse models [28]. When low concentrations of an analyte under investigation are present in a sample, such as in the case of $\mathrm{A} \beta$ oligomers as a potential neurotoxin, auto-antibodies may pose additional particular challenges linked to the analytical sensitivity of the technology platforms used for their detection [16].

Naturally occurring antibodies against $A \beta$ are found in CSF and plasma of healthy and diseased subjects. Patients with AD have lower, higher, or identical levels of serum anti-A $\beta$ antibodies to healthy age-matched individuals [24]. The serum anti-A $\beta$ antibody titer was higher in patients with mild cognitive impairment who progressed to AD than in stable cases [29]. The level of auto-antibodies to $\mathrm{A} \beta$ did not correlate with the likelihood of developing AD [30], although titers were negatively correlated with the cognitive status [31]. Henkel and colleagues [24] showed that the concentration of the large A $\beta$-binding particles (LAPs) was highly variable among individuals and that the levels were not disease-specific. The abovementioned studies use different technologies and are not always qualified extensively for the intended use.

The immunoreactivity was 30 to 230 times lower in CSF than in plasma [32]. Anti-A $\beta$ IgGs were restricted to the IgG1 and IgG3 subclass, which are the most potent IgG subclasses in activating the complement classical pathway through $\mathrm{C} 1 \mathrm{q}$ binding [33]. Several types of antibodies recognize the higher order $A \beta$ assemblies, including oligomers and post-translationally modified peptides, rather than the monomeric forms [32]. The signal in unvaccinated nonTg mice was specific for the fulllength $A \beta$ peptide, while for anti- $A \beta$ vaccines, the predominant epitope is in the amino-terminal domain [34].

In the study of Henkel and colleagues [24], confocal microscopy for single molecular imaging was used to identify and classify distinct types of LAPs. Double labeling with anti-A $\beta$ and anti-IgG antibodies characterized LAP-3 and LAP-4 as immune complexes of A $\beta$ and IgG. The LAPs are most probably directed against either a non-pathogenic form of $A \beta$ or aggregated $A \beta 1-42$.

The antibody-antigen complex can be dissociated by incubation at low $\mathrm{pH}[34,35]$. The increase in $\mathrm{A} \beta$ autoantibody levels is higher in $\mathrm{AD}$ than in controls, again possibly affecting clinical accuracy. Differences between studies may relate to a diversity of methods used for anti$\mathrm{A} \beta$ assessment, the validation status of the assays, and detailed investigation of the relevance of the generated output. One approach to solve this issue could be the development of a multi-analyte assay format, either (i) by inclusion of an extra region with a non-analyte specific 
$\mathrm{mAb}$ used as capture antibody (direct bridging between mAbs) [17], or (ii) by the integration of an internal control with $A \beta$ coupled to a specific region to verify the presence of anti-A $\beta$ antibodies. This approach will help to understand the contribution of $\mathrm{A} \beta$ auto-antibodies to the output signal of the assay.

\section{Analyte-specific interferences induced by therapeutics}

Many pharmaceutical and biotechnology companies perform studies with $A \beta$-lowering drugs: vaccination with peptides (active) or immunization with mAbs (passive immunization) (Table 1). Vaccination improves the brain pathology and protects against cognitive decline, while passive immunization with $A \beta$ antibodies reduces plaque burden [2]. Therapeutic compounds, however, can directly interfere with assay design and assay modifications are required dependent on the therapeutic approach. Short amino-terminal-specific A $\beta$-peptides used for immunization will compete for binding with the mAbs if amino-terminal specific mAbs are used, while the therapeutic mAbs can mask the binding site of the analyte, resulting in an underestimation of the levels in a sample.

Analyte-specific interferences induced by a specific therapeutic (with a defined molecular nature) can be identified easily and reproducibly by spiking of the drug in relevant concentrations in the sample of interest, followed by its quantification using different technologies and/or antibody pair combinations. In active immunization trials with a more heterogeneous antibody spectrum, it might be more relevant to include antibodyindependent techniques (for example, mass spectrometry). Although the latter might not be relevant for verification of efficacy of drug treatment since these techniques quantify the total amount of $A \beta$ in a sample. The monomeric, non-bound $A \beta$ could be the most relevant $A \beta$ isoform to verify for a disease-modifying effect. As such, it will be obligatory to develop assays in biological fluids that make a distinction between free analyte, and the analyte bound to confounding factors (for example, endogenous antibodies, therapeutic compounds), or conformational forms. Comparison with the total amount of $A \beta$, independent of the isoform, could be an extra advantage for clinical interpretation of the data.

\section{Conclusion}

Measurements of low concentrations of $A \beta 1-42$ in biological samples are impeded by the presence of nonspecific interactions. These documented confounders need to be addressed during the development phase of the product to improve robustness, respecting the balance between the required assay sensitivity and precision. The impact of assay modifications on the accuracy of clinical decisions still has to be determined.

\section{Abbreviations}

$A \beta, \beta$-amyloid; $A D$, Alzheimer's disease; CSF, cerebrospinal fluid; $H A$ heterophilic antibodies; IVD, in vitro diagnostic biomarker test; LAP, large A $\beta$ binding particle; mAb, monoclonal antibody.

\section{Competing interests}

The authors declare that they have no competing interests.

\section{Author details}

${ }^{1}$ ADxNeurosciences, Technologiepark 4, 9052, Gent, Belgium. ${ }^{2}$ NextGen Sciences, Diagnostics, Boston, MA 02110, USA.

Published: 17 October 2012

\section{References}

1. Draft Guidance for Industry and Food and Drug Administration Staff - In vitro companion diagnostic devices [http://www.fda.gov/medicaldevices/ deviceregulationandguidance/guidancedocuments/ucm262292.htm]

2. Blennow K: Biomarkers in Alzheimer's disease drug development. Nat Med 2010, 16:1218-1222.

3. Jack CR, Knopman DS, Jagust WJ, Shaw LM, Aisen PS, Weiner MW, Petersen RC, Trojanowski JQ: Hypothetical model of dynamic biomarkers of the Alzheimer's pathological cascade. Lancet Neurol 2010, 9:119-128.

4. Lukiw WJ: Amyloid beta $(A \beta)$ peptide modulators and other current treatment strategies for Alzheimer's disease (AD). Exp Opin Emerging Drugs 2012, 17:43-60

5. Vanderstichele $H$, Bibl M, Engelborghs S, Le Bastard N, Lewczuk P, Molinuevo L, Parnetti L, Perret-Liaudet A, Shaw LM, Teunissen C, Wouters D, Blennow K: Standardization of preanalytical aspects of cerebrospinal fluid biomarker testing for Alzheimer's disease diagnosis: a consensus paper from the Alzheimer's Biomarkers Standardization Initiative. Alzheimer's Dement 2012, 8:65-73.

6. Andreasson $\mathrm{U}$, Vanmechelen $\mathrm{E}$, Shaw $\mathrm{L}$, Zetterberg $\mathrm{H}$, Vanderstichele $\mathrm{H}$ : Analytical aspects of molecular Alzheimer's disease biomarkers. Biomarkers Med 2012, 6:377-389.

7. Reverberi $R$, Reverberi $L$ : Factors affecting the antigen-antibody reaction. Blood Transfus 2007, 5:227-240.

8. Vanderstichele H, Van Kerschaver E, Hesse C, Davidsson P, Buyse M-A, Andreasen N, Minthon L, Wallin A, Blennow K, Vanmechelen E: Standardization of measurement of $\beta$-amyloid(1-42) in cerebrospinal fluid and plasma. Amyloid 2000, 7:245-258.

9. Rubinstein A, Lyubchenko YL, Sherman S: Dynamic properties of $\mathrm{pH}$ dependent structural organization of the amyloidogenic $\beta$-protein (1-40). Prion 2009, 3:31-43.

10. Bjerke M, Portelius E, Minthon L, Wallin A, Anckarsäter H, Anckarsäter R, Andreasen N, Zetterberg H, Andreasson U, Blennow K: Confounding factors influencing amyloid beta concentration in cerebrospinal fluid. Int $J$ Alzheimers Dis 2010, pii:986310

11. Sancesario GM, Esposito Z, Nuccetelli M, Bernardini S, Sorge R, Martorana A, Federici G, Bernardi G, Sancesario G: A 1 1-42 detection in CSF of Alzheimer's disease is influenced by temperature: indication of reversible $A \beta 1-42$ aggregation. Exp Neurol 2010, 223:371-376.

12. Wadsley JJ, Watt RM: The effect of $\mathrm{pH}$ on the aggregation of biotinylated antibodies and on the signal-to-noise observed in immunoassays utilizing biotinylated antibodies. J Immuno/ Meth 1987, 103:1-7.

13. Das U, Hariprasad G, Ethayathulla AS, Manral P, Das TK, Pasha S, Mann A, Ganguli M, Verma AK, Bhat R, Chandrayan SK, Ahmed S, Sharma S, Kaur P, Singh TP, Srinivasan A: Inhibition of protein aggregation: supramolecular assemblies of arginine hold the key. PLos One 2007, 11:1-9.

14. Levinson SS, Miller JJ: Towards a better understanding of heterophile (and the like) antibody interference with modern immunoassays. Clin Chim Acta 2002, 325:1-15

15. Bjerner J, Bormer OP, Nustad K: The war on heterophilic antibody interference. Clin Chem 2005, 51:9-11.

16. Sehlin D, Söllvander S, Paulie S, Brundin RM, Ingelsson M, Lannfelt L, Pettersson $\mathrm{FE}$, Englund $\mathrm{H}$ : Interference from heterophilic antibodies in amyloid- $\beta$ oligomer ELISAs. J Alzheimers Dis 2010, 21:1295-1301.

17. Vanderstichele H, De Meyer G, Shapiro F, Engelborghs S, De Deyn PP, Shaw LM, Trojanowski JQ: Alzheimer's disease biomarkers: from concept to clinical utility. In: Biomarkers for early diagnosis of Alzheimer's Disease. Edited by Galimberti D, Scarpini E. Nova Science Publishers, Inc.; 2008:81-122. 
18. Stenman U-F: Improving immunoassay performance by antibody engineering. Clin Chem 2005, 51:801-802.

19. Kricka LJ: Human anti-animal antibody interferences in immunological assays. Clin Chem 1999, 45:942-956.

20. Hansson $\mathrm{O}$, Zetterberg $\mathrm{H}$, Vanmechelen $\mathrm{E}$, Vanderstichele $\mathrm{H}$, Andreasson $\mathrm{U}$, Londos $E$, Wallin A, Minthon L, Blennow K: Evaluation of plasma $A \beta 40$ and $A \beta 42$ as predictors of conversion to Alzheimer's disease in patients with mild cognitive impairment. Neurobiol Aging 2010, 31:357-367.

21. Cullen VC, Fredenburg RA, Evans C, Conliffe PR, Solomon ME: Development and advanced validation of an optimized method for the quantitation of $A \beta_{42}$ in human cerebrospinal fluid. AAPS J 2012, 14:510-518

22. Slemmon JR, Meredith J, Guss V, Andreasson U, Andreasen N, Zetterberg H, Blennow K: Measurement of $A \beta 1-42$ in cerebrospinal fluid is influenced by matrix effects. J Neurochem 2012, 120:325-333.

23. de Jager W, Prakken BJ, Bijlsma JWJ, Kuis W, Rijkers GT: Improved multiplex immunoassay performance in human plasma and synovial fluid following removal of interfering heterophilic antibodies. J Immuno/ Methods 2005, 300:124-135.

24. Henkel AW, Dittrich PS, Groemer TW, Lemke EA, Klingauf J, Klafki HW, Lewczuk P, Esselman H, Schwille P, Kornhuber J, Wiltfang J: Immune complexes of auto-antibodies against $A \beta 1-42$ peptides patrol cerebrospinal fluid of non-Alzheimer's patients. Mol Psych 2007, 12:601-610.

25. Kellner A, Matschke J, Bernreuther C, Moch H, Ferrer I, Glatzel M: Autoantibodies against beta-amyloid are common in Alzheimer's disease and help control plaque burden. Ann Neurol 2009, 65:24-31.

26. Ray S, Britschgi M, Herbert C, Takeda-Uchimura Y, Boxer A, Blennow K, Friedman LF, Galasko DR, Jutel M, Karydas A, Kaye JA, Leszek J, Miller BL, Minthon L, Quinn JF, Rabinovici GD, Robinson WH, Sabbagh MN, So YT, Sparks DL, Tabaton M, Tinklenberg J, Yesavage JA, Tibshirani R, Wyss- Coray T: Classification and prediction of clinical Alzheimer's diagnosis based on plasma signaling proteins. Nat Med 2007, 13:1359-1362.

27. Nagele RG, Clifford PM, Siu G, Levin EC, Acharya NK, Han M, Kosciuk MC Venkataraman V, Zavareh S, Zarrabi S, Kinsler K, Thaker NG, Nagele EP, Dash J, Wang $H Y$, Levitas A: Brain-reactive autoantibodies prevalent in human sera increase intraneuronal amyloid- $\beta_{1-42}$ deposition. J Alzheimers Dis 2011, 25:605-622.

28. Wilcock DM, Gordon MN, Ugen KE, Gottschall PE, DiCarlo G, Dickey C, Boyett KW, Jantzen PT, Connor KE, Melachrino J, Hardy J, Morgan D: Number of Abeta inoculations in APP+PS1 transgenic mice influences antibody titers, microglial activation, and congophilic plaque levels. DNA Cell Biol 2001, 20:731-736

29. Storace D, Cammarata S, Borghi R, Sanguineti R, Giliberto L, Piccini A, Pollero V, Novello C, Caltagirone C, Smith MA, Bossù P, Perry G, Odetti P, Tabaton M: Elevation of $\beta$-amyloid 1-42 autoantibodies in the blood of amnestic patients with mild cognitive impairment. Arch Neurol 2010, 67:867- 872.

30. Weksler ME, Relkin N, Turkenich R, LaRusse S, Zhou L, Szabo P: Patients with Alzheimer disease have lower levels of serum anti-amyloid peptide antibodies than healthy elderly individuals. Exp Gerontol 2002, 37:943-948,

31. Mruthinti S, Buccafusco JJ, Hill WD, Waller UL, Jackson TW, Zamrini EY, Schade RF: Autoimmunity in Alzheimer's disease: increased levels of circulating IgGs binding Abeta and RAGE peptides. Neurobiol Aging 2004, 25:1023-1032

32. Britschgi M, Olin CE, Johns HT, Takeda-Uchimura Y, LeMieux MC, Rufibach K, Rajadas J, Zhang H, Tomooka B, Robinson WH, Clark CM, Fagan AM, Galasko DR, Holtzman DM, Jutel M, Kaye JA, Lemere CA, Leszek J, Li G, Peskind ER, Quinn JF, Yesavage JA, Ghiso JA, Wyss-Coray T: Neuroprotective natural antibodies to assemblies of amyloidogenic peptides decrease with normal aging and advancing Alzheimer's disease. Proc Natl Acad Sci U S A 2009, 106:12145-12150.

33. Dorothée G, Bottlaender M, Moukari E, de Souza LC, Maroy R, Corlier F, Colliot $O$, Chupin M, Lamari F, Lehéricy S, Dubois B, Sarazin M, Aucouturier P: Distinct patterns of anti amyloid- $\beta$ Antibodies in typical and atypical Alzheimer Disease. Arch Neurol 2012, 18:1-5.
34. Li Q, Gordon M, Cao C, Ugen KE, Morgan D: Improvement of a low pH antigen-antibody dissociation procedure for ELISA measurement of circulating anti-Abeta antibodies. BMC Neurosci 2007, 8:22.

35. Gustaw KA, Garrett MR, Lee HG, Castellani RJ, Zagorski MG, Prakasam A, Siedlak SL, Zhu X, Perry G, Petersen RB, Friedland RP, Smith MA: Antigenantibody dissociation in Alzheimer disease: a novel approach to diagnosis. J Neurochem 2008, 106:1350-1356.

36. Panza F, Frisardi V, Imbimbo BP, Seripa D, Paris F, Santamato A, D'Onofrio G, Logroscino G, Pilotto A, Solfrizzi V: Anti- $\beta$-amyloid immunotherapy for Alzheimer's disease: focus on bapineuzumab. Curr Alzheimer Res 2011, 8:808-817.

37. Black RS, Sperling RA, Safirstein B, Motter RN, Pallay A, Nichols A, Grundman $M: A$ single ascending dose study of bapineuzumab in patients with Alzheimer disease. Alzheimer Dis Assoc Disord 2010, 24:198-203.

38. Imbimbo BP, Ottonello S, Frisardi V, Solfrizzi V, Greco A, Seripa D, Pilotto A, Panza F: Solanezumab for the treatment of mild-to-moderate Alzheimer's disease. Expert Rev Clin Immunol 2012, 8:135-149.

39. Uenaka K, Nakano M, Willis BA, Friedrich $S$, Ferguson-Sells L, Dean RA, leiri I, Siemers ER: Comparison of pharmacokinetics, pharmacodynamics, safety, and tolerability of the amyloid $\beta$ monoclonal antibody solanezumab in Japanese and white patients with mild to moderate alzheimer disease. Clin Neuropharmacol 2012, 35:25-29.

40. Delrieu J, Ousset PJ, Vellas B: Gantenerumab for the treatment of Alzheimer's disease. Expert Opin Biol Ther 2012, 12:1077-1086.

41. Ostrowitzki S, Deptula D, Thurfell L, Barkhof F, Bohrmann B, Brooks DJ, Klunk WE, Ashford E, Yoo K, Xu ZX, Loetscher H, Santarelli L: Mechanism of amyloid removal in patients with Alzheimer disease treated with gantenerumab. Arch Neurol 2012, 69:198-207.

42. Freeman GB, Lin JC, Pons J, Raha NM: 39-week toxicity and toxicokinetic study of ponezumab (PF-04360365) in cynomolgus monkeys with 12-week recovery period. J Alzheimers Dis 2012, 28:531-541.

43. Muhs A, Hickman DT, Pihlgren M, Chuard N, Giriens V, Meerschman C, van der Auwera I, van Leuven F, Sugawara M, Weingertner MC, Bechinger B, Greferath R, Kolonko N, Nagel-Steger L, Riesner D, Brady RO, Pfeifer A, Nicolau C: Liposomal vaccines with conformation-specific amyloid peptide antigens define immune response and efficacy in APP transgenic mice. Proc Natl Acad Sci U S A 2007, 104:9810-9815.

44. Dodel R, Neff F, Noelker C, Pul R, Du Y, Bacher M, Oertel W: Intravenous immunoglobulins as a treatment for Alzheimer's disease: rationale and current evidence. Drugs 2010, 70:513-528.

45. Blennow K, Zetterberg H, Rinne JO, Salloway S, Wei J, Black R, Grundman M, Liu E; for the AAB-001 201/202 Investigators: Effect of immunotherapy with Bapineuzumab on cerebrospinal fluid biomarker levels in patients with mild to moderate Alzheimer disease. Arch Neurol 2012, 69:1002-1010.

46. Winblad B, Andreasen N, Minthon L, Floesser A, Imbert G, Dumortier T, Maguire RP, Blennow K, Lundmark J, Staufenbiel M, Orgogozo JM, Graf A: Safety, tolerability, and antibody response of active $A \beta$ immunotherapy with CAD106 in patients with Alzheimer's disease: randomised, doubleblind, placebo-controlled, first-in-human study. Lancet Neurol 2012, 11:567-650.

47. Schneeberger A, Mandler M, Otawa O, Zauner W, Mattner F, Schmidt W: Development of AFFITOPE vaccines for Alzheimer's disease (AD) - from concept to clinical testing. J Nutr Health Aging 2009, 13:264-267.

doi:10.1186/alzrt142

Cite this article as: Venderstichele $\mathrm{H}$, et al.: Potential sources of interference on Abeta immunoassays in biological samples. Alzheimer's Research \& Therapy 2012, 4:39. 